\title{
Young Nursing and Medical Students' Knowledge and Attitudes Toward Contraceptive Methods
}

\author{
Scarano-Pereira Juan-Pablo \\ Complutense University of Madrid \\ Martinino Alessandro \\ Sapienza University of Rome \\ Francesca Manicone \\ Sapienza University of Rome \\ Álvarez-García Cristina \\ University of Jaén \\ Ortega-Donaire Lucía \\ University of Jaén \\ Clavijo-Chamorro María-Zoraida \\ University of Extremadura \\ López-Medina Isabel M \\ University of Jaén \\ Álvarez-Nieto Carmen ( $\nabla$ calvarez@ujaen.es ) \\ University of Jaén \\ Sanz-Martos Sebastián \\ University of Jaén
}

\section{Research Article}

Keywords: Contraception, Unwanted pregnancy, Primary prevention, Knowledge, Young adult

Posted Date: January 6th, 2022

DOI: https://doi.org/10.21203/rs.3.rs-1191863/v1

License: (a) (1) This work is licensed under a Creative Commons Attribution 4.0 International License. Read Full License 


\section{Abstract}

Background: Living sexuality fully and without risk to one's health is an international priority. The youth age group has specific characteristics that make it a particularly vulnerable group for adverse consequences such as unwanted pregnancies or sexually transmitted infections. Health professionals are an important group to address this issue; however, to achieve a good result, sufficient knowledge is required to solve all the issues. This study aimed to assess the level of knowledge of young university students studying toward a nursing or medical degree.

Methods: A descriptive cross-sectional study of young medical and nursing students was conducted. The Sexuality and Contraceptive Knowledge Instrument scale was used to measure knowledge level. A bivariate analysis was conducted using the Mann-Whitney $U$ test or the Kruskal-Wallis $\mathrm{H}$ test, depending on the number of categories of the independent variable. Finally, a multivariate analysis was conducted using a multiple linear regression model, establishing the level of knowledge as the dependent variable and all variables that obtained statistical significance in the bivariate analysis as predictors.

Results: Participants had a good level of knowledge, with $77.9 \%$ answering $50 \%$ of the questions correctly. Before training, $34.15 \%$ of the participants did not pass $50 \%$ of the questions asked. This percentage decreased to $12.87 \%$ after receiving sexuality training during the university degrees. The main training gaps were found for the items on hormonal contraceptive methods. The bivariate analysis showed that female participants had significantly higher knowledge scores, as did those who had used a hormonal contraceptive method during the most recent intercourse or were aware of family planning centers. These variables maintained their significant effect at the multivariate level, obtaining two models with good explanatory power for participants of both university degrees.

Conclusion: The general level of knowledge of the healthcare students was high and sufficient after receiving training during the university degree. The main training gap was found for items on hormonal contraceptive methods, which should be emphasized in future training programs.

\section{Background}

Sexual health can be defined as a state of physical, emotional, mental, and social well-being in the field of sexuality and is recognized as a global priority by the World Health Organization [1]. Related to the concept of sexual health is the concept of sexuality as a fundamental dimension of the human being, which becomes more evident from the biological and socio-cultural changes derived from puberty in adolescence. At this stage, adolescents and young people may be physically ready to begin their sexual life but may not have the psychological and conceptual preparation to begin it safely [2].

The youth age group of 18-25 is considered at particular risk for experiencing adverse consequences such as sexually transmitted infections, unwanted pregnancies, or abortions [3-6]. According to previous research, the highest prevalence of sexually transmitted infections is found in the under-25 age group, as well as the highest rate of voluntary termination of pregnancy [7-9]. These consequences may have repercussions in terms of academic and professional opportunities. One of the reasons given in previous research for this high prevalence is a decrease in the age at first sexual intercourse, which may increase the period of sexual activity of young people and the total number of sexual partners. On the other hand, the psychological characteristics adolescents and youth, such as invulnerability or false perception of risk, may make them particularly susceptible to adopting risky behaviors related to their sexuality $[2,5,10,11]$.

In order to experience sexuality without associated risks, it is necessary to have a sufficient level of knowledge to develop positive attitudes toward the use of the different contraceptive options available. Health professionals are quality sources of information that young people can approach for information; however, access to healthcare by young people is often low. Moreover, youth show a high prevalence of using other sources of information that do not require two-way interaction, such as the internet. Other sources of information that were used previously, such as peer groups or parents, are now less prevalent $[12,13]$. Family planning centers are an important option for the education of young people, where health professionals can provide quality training adapted to their needs. Previous research has found higher levels of knowledge, more positive attitudes toward the use of contraceptive methods, and a lower rate of sexually transmitted infections in young people who are aware of these centers and have used them [14-16].

Young healthcare students are a population vulnerable to risky sexual practices due to the characteristics of their age group. Hence, they need an adequate level of knowledge about sexuality and contraceptive methods to experience it safely. In addition, as future health professionals, they need to acquire the knowledge and skills to provide quality information in health care centers or family 
planning centers. Therefore, this study aimed to assess the level of knowledge about sexuality and contraceptive methods of young students of healthcare degrees.

\section{Methods}

\section{Participants and study modules.}

A descriptive cross-sectional study was carried out with students studying toward a Medical degree at the Complutense University of Madrid and toward a Nursing Degree at the University of Jaén, aged 18 and 25 years.

\section{Procedure}

Data were collected by trained persons from healthcare students studying either a six-year medical degree or four-year nursing degree between October 2020 and March 2021. The information was collected in university seminars. The self-administered data collection notebook in paper format included the following:

- Socio-demographic variables: Sex, Age, University, Academic year, Having received training on sexuality and contraceptive methods during the medical or Nursing degree, Having a partner at the time of the study, Have viewed pornographic material during adolescence, Currently viewing pornographic material, Perceived usefulness of using pornographic material as an educational element, Source of information used to obtain information on sexuality and contraceptive methods, Desired source of information to obtain information on sexuality and contraceptive methods, Self-perceived level of knowledge about sexuality and contraceptive methods, and Self-perceived knowledge gap.

- Level of knowledge about sexuality and contraceptive methods: Measured through the Sexuality and Contraceptive Knowledge Instrument scale, validated in Spanish and consisting of 15 items with three response options (True/False and Don't know, no answer). The scale showed a reliability of 0.99 for the items and 0.74 for the persons; the intraclass correlation coefficient for testretest reliability obtained a value of 0.81 . [17] The score range is between 0 and 15 , and the level of knowledge is categorized as follows: excellent ( $\geq 90 \%$ correct), very good ( $89-70 \%)$, good $(69-50 \%)$, and insufficient $(<50 \%)$.

- Sexual intercourse variables: Ever had penetrative sex, Age at first intercourse, Use of contraceptive method at first intercourse, Contraceptive method used or reason for not using any, Use of contraceptive method at last intercourse, and Contraceptive method used or reason for not using any.

- Knowledge about Family Planning Centers (FPC): This was assessed by a dichotomous question (Yes/No). Participants who answered in the affirmative were asked to respond to 6 statements by indicating whether they considered them True, False or Don't know, no answer. If the number of correct answers is above $50 \%$, the student was considered to be aware of the FPCs. This section of the questionnaire was designed ad hoc and was peer-reviewed.

\section{Data analysis.}

Descriptive statistics for all data and the questionnaire score were calculated. Bivariate analyses were performed, establishing as dependent variable the score on the knowledge scale, and as independent variables the socio-demographic variables, sexual relations variables, and the variables on knowledge of FCPs. All the bivariate analyses were differentiated by the university degree that the participants were studying as variables related to training were also analyzed. Moreover, the questionnaires were carried out in different academic years, and we could commit a confounding bias when making comparisons by the socio-demographic variables if joining both groups. The normality of the distribution was assessed by analyzing the histogram, skewness, kurtosis, and the Kolmogorov-Smirnov test. Contrasts were performed using the non-parametric Mann-Whitney U or Kruskal-Wallis H statistic depending on the number of categories of the independent variable.

A multivariate analysis was performed using a multiple linear regression model, establishing the level of knowledge as the dependent variable and those variables that obtained statistical significance at the bivariate level as predictor variables. The model's goodness of fit was calculated using the value of $R^{2}$. All analyses were performed with the statistical program SPSS 24.0 , and a value of $p<0.05$ was established as the level of statistical significance.

\section{Results}


The initial sample consisted of 696 participants. Of these, 11 were excluded for not completing the questionnaire in its entirety and 28 for being over 25 years of age. The final sample included 657 participants (303 from the Nursing Degree and 354 from the Medical degree), with a mean age of 20.65 (SD: 2.32) years. The main source of information used to learn about sexuality and contraceptive methods was the internet, followed by Healthcare professionals. The main sources of information requested by participants were Talks on sexual and reproductive health and digital resources on the internet with high-quality information. The leading information gap identified was for non-coital sexual relations, followed by information about contraceptive methods and where to obtain quality information. Just over half (55.4\%) of the sample viewed pornographic material during adolescence, with a mean age of onset of 15.18 (SD: 2.42) years. Table 1 shows the demographic characteristics of the sample. 
Demographic characteristics of the sample

\begin{tabular}{|c|c|c|c|c|}
\hline VARIABLE & CATEGORY & NURSING & MEDICINE & TOTAL \\
\hline \multirow[t]{2}{*}{ Gender } & Men & 65 & 71 & 136 \\
\hline & Women & 238 & 283 & 521 \\
\hline Age (years) & & $\begin{array}{l}19.75 \\
(1.83)\end{array}$ & $\begin{array}{l}21.42 \\
(2.42)\end{array}$ & $\begin{array}{l}20.65 \\
(2.32)\end{array}$ \\
\hline \multirow[t]{6}{*}{ Academic year } & 1st Year & 80 & 63 & - \\
\hline & 2nd Year & 109 & 53 & - \\
\hline & 3rd Year & 24 & 46 & - \\
\hline & 4th Year & 90 & 28 & - \\
\hline & 5th Year & - & 99 & - \\
\hline & 6th Year & - & 65 & - \\
\hline \multirow[t]{2}{*}{ Received sexuality training during the university degree } & Yes & 201 & 114 & 345 \\
\hline & No & 102 & 210 & 312 \\
\hline \multirow[t]{2}{*}{ Has a partner } & Yes & 186 & 197 & 383 \\
\hline & No & 117 & 157 & 274 \\
\hline \multirow{4}{*}{$\begin{array}{l}\text { Source of information used to obtain information on sexuality } \\
\text { and contraceptive methods }\end{array}$} & Internet & 119 & 198 & 317 \\
\hline & Healthcare professionals & 111 & 74 & 185 \\
\hline & Family & 22 & 15 & 37 \\
\hline & Friends & 51 & 67 & 118 \\
\hline \multirow[t]{3}{*}{$\begin{array}{l}\text { Source of information desired to obtain information on } \\
\text { sexuality and contraceptive methods }\end{array}$} & $\begin{array}{l}\text { Talks on sexual and } \\
\text { reproductive health }\end{array}$ & 175 & 127 & 302 \\
\hline & Internet & 122 & 222 & 344 \\
\hline & TV campaigns & 6 & 5 & 11 \\
\hline \multirow[t]{2}{*}{ Pornography use during adolescence } & Yes & 180 & 184 & 364 \\
\hline & No & 123 & 170 & 293 \\
\hline Age of use & & $\begin{array}{l}15.06 \\
(2.29)\end{array}$ & $\begin{array}{l}15.28 \\
(2.53)\end{array}$ & $\begin{array}{l}15.18 \\
(2.42)\end{array}$ \\
\hline \multirow[t]{4}{*}{ Perception of the effectiveness of pornographic material } & Good & 4 & 9 & 13 \\
\hline & Regular & 20 & 31 & 51 \\
\hline & Bad & 64 & 62 & 126 \\
\hline & Very bad & 109 & 116 & 225 \\
\hline \multirow{3}{*}{$\begin{array}{l}\text { Self-perception of their knowledge about sexuality and } \\
\text { contraceptive methods }\end{array}$} & Good & 108 & 122 & 230 \\
\hline & Regular & 102 & 124 & 226 \\
\hline & Bad & 93 & 108 & 201 \\
\hline \multirow[t]{2}{*}{ Had penetrative sex } & Yes & 239 & 259 & 498 \\
\hline & No & 64 & 95 & 159 \\
\hline
\end{tabular}




\begin{tabular}{|c|c|c|c|c|}
\hline VARIABLE & CATEGORY & NURSING & MEDICINE & TOTAL \\
\hline Age at first intercourse & & $\begin{array}{l}16.40 \\
(1.29)\end{array}$ & $\begin{array}{l}17.35 \\
(1.99)\end{array}$ & $\begin{array}{l}16.89 \\
(1.76)\end{array}$ \\
\hline \multirow[t]{2}{*}{ Use of any contraceptive method during first intercourse } & Yes & 213 & 231 & 444 \\
\hline & No & 26 & 28 & 54 \\
\hline \multirow[t]{3}{*}{ Contraceptive method used during first intercourse } & Male condom & 206 & 207 & 413 \\
\hline & $\begin{array}{l}\text { Hormonal contraceptive } \\
\text { methods }\end{array}$ & 5 & 23 & 28 \\
\hline & Withdrawal method & 2 & 1 & 3 \\
\hline \multirow[t]{4}{*}{$\begin{array}{l}\text { Reason for not using any contraceptive method during first } \\
\text { intercourse }\end{array}$} & $\begin{array}{l}\text { Improvised sexual } \\
\text { intercourse }\end{array}$ & 18 & 22 & 40 \\
\hline & Were not planning to use it & 3 & 4 & 7 \\
\hline & $\begin{array}{l}\text { Shame to get a } \\
\text { contraceptive method }\end{array}$ & 5 & - & 5 \\
\hline & Alcohol consumption & - & 2 & 2 \\
\hline \multirow{2}{*}{$\begin{array}{l}\text { Use of any contraceptive method during most recent } \\
\text { intercourse }\end{array}$} & Yes & 201 & 227 & 428 \\
\hline & No & 38 & 32 & 70 \\
\hline \multirow[t]{3}{*}{ Contraceptive method used during the most recent intercourse } & Male condom & 136 & 146 & 282 \\
\hline & $\begin{array}{l}\text { Hormonal contraceptive } \\
\text { methods }\end{array}$ & 62 & 78 & 140 \\
\hline & Withdrawal method & 3 & 3 & 6 \\
\hline \multirow[t]{4}{*}{$\begin{array}{l}\text { Reason for not using any contraceptive method during most } \\
\text { recent intercourse }\end{array}$} & $\begin{array}{l}\text { Improvised sexual } \\
\text { intercourse }\end{array}$ & 10 & 11 & 21 \\
\hline & Reduce pleasure & 10 & 6 & 16 \\
\hline & Were not planning to use it & 18 & 13 & 31 \\
\hline & I have a permanent partner & - & 2 & 2 \\
\hline \multirow[t]{2}{*}{ Knowledge about FPCs } & Yes & 99 & 129 & 228 \\
\hline & No & 204 & 225 & 429 \\
\hline
\end{tabular}

The average score for the knowledge scale was 8.73 (2.87). Medical students had a significantly higher score (9.14 [2.81] vs. 8.58 [2.893]; $p=0.011$ ). Regardless of the academic degree they studied,77.9\% of the participants obtained a knowledge level value rated as good, very good, or excellent. Before receiving the relevant sexuality education in either of the university degrees, $34.15 \%$ of the participants obtained "insufficient" knowledge, a percentage that decreased to $12.87 \%$ after receiving this training during their degree; this difference was statistically significant $(p<0.05)$. The items with the highest percentage of lack of knowledge were the items on hormonal contraceptive methods such as the contraceptive pill, vaginal ring or contraceptive patch, regardless of the academic level of the participants, reaching an error rate and lack of knowledge of $54.57 \%$. The items on using the male condom or general sexuality concepts obtained a percentage of correct answers close to $90 \%$ in both groups.

In the samples of both university students, we found similar results at the bivariate level, finding common significant variables such as female sex, having a partner at the time of the study, having penetrative sex prior to the time of the study, using a hormonal contraceptive method during the most recent intercourse, and know about the FPCs. With respect to age, we found a moderate significant positive correlation in both samples, indicating that older participants at the time of the study had a higher level of knowledge. Table 2 shows the bivariate contrasts for both university grades. 


\begin{tabular}{|c|c|c|c|c|}
\hline VARIABLE & NURSING & CONTRAST & MEDICINE & CONTRAST \\
\hline \multicolumn{5}{|l|}{ Gender } \\
\hline Men & $\begin{array}{l}7.48 \pm \\
2.87\end{array}$ & $Z=-2.563^{*}$ & $\begin{array}{l}8.01 \pm \\
2.84\end{array}$ & $\begin{array}{l}Z= \\
-3.779 * \star\end{array}$ \\
\hline Women & $\begin{array}{l}8.26 \pm \\
2.82\end{array}$ & & $\begin{array}{l}9.42 \pm \\
2.73\end{array}$ & \\
\hline Age & & $\begin{array}{l}\text { Rho }= \\
0.340 * *\end{array}$ & & $\begin{array}{l}\text { Rho }= \\
0.524^{\star \star}\end{array}$ \\
\hline \multicolumn{5}{|l|}{ Academic course } \\
\hline 1st Year & $\begin{array}{l}6.51 \pm \\
2.07\end{array}$ & \multirow[t]{6}{*}{$\begin{array}{l}\chi^{2}= \\
77.833^{\star \star}\end{array}$} & $\begin{array}{l}7.08 \pm \\
2.07\end{array}$ & \multirow[t]{6}{*}{$\begin{array}{l}\chi^{2}= \\
117.512 \star \star\end{array}$} \\
\hline 2nd Year & $\begin{array}{l}10.11 \pm \\
2.23\end{array}$ & & $\begin{array}{l}7.11 \pm \\
2.07\end{array}$ & \\
\hline 3rd Year & $\begin{array}{l}9.25 \pm \\
2.52\end{array}$ & & $\begin{array}{l}8.52 \pm \\
2.48\end{array}$ & \\
\hline 4th Year & $\begin{array}{l}8.40 \pm \\
2.3 .23\end{array}$ & & $\begin{array}{l}10.14 \pm \\
2.43\end{array}$ & \\
\hline 5th Year & & & $\begin{array}{l}10.37 \pm \\
2.73\end{array}$ & \\
\hline 6th Year & & & $\begin{array}{l}10.91 \pm \\
1.93\end{array}$ & \\
\hline \multicolumn{5}{|c|}{ Received sexuality training during the university degree } \\
\hline Yes & $\begin{array}{l}8.79 \pm \\
2.86\end{array}$ & \multirow[t]{2}{*}{$\begin{array}{l}Z= \\
-4.587 * \star\end{array}$} & $\begin{array}{l}10.41 \pm \\
2.47\end{array}$ & \multirow[t]{2}{*}{$Z=-8.628$} \\
\hline No & $\begin{array}{l}7.22 \pm \\
2.42\end{array}$ & & $\begin{array}{l}7.93 \pm \\
2.57\end{array}$ & \\
\hline \multicolumn{5}{|c|}{$\begin{array}{l}\text { Source of information used to obtain information on sexuality and } \\
\text { contraceptive methods }\end{array}$} \\
\hline Internet & $\begin{array}{l}7.82 \pm \\
2.80\end{array}$ & \multirow[t]{4}{*}{$\begin{array}{l}\chi^{2}= \\
26.739 * \star\end{array}$} & $\begin{array}{l}9.04 \pm \\
2.85\end{array}$ & \multirow[t]{4}{*}{$\begin{array}{l}\chi^{2}= \\
15.227 * \star\end{array}$} \\
\hline Healthcare professionals & $\begin{array}{l}9.30 \pm \\
2.65\end{array}$ & & $\begin{array}{l}10.12 \pm \\
2.67\end{array}$ & \\
\hline Family & $\begin{array}{l}7.53 \pm \\
2.89\end{array}$ & & $\begin{array}{l}8.63 \pm \\
2.52\end{array}$ & \\
\hline Friends & $\begin{array}{l}7.14 \pm \\
2.12\end{array}$ & & $\begin{array}{l}7.87 \pm \\
3.04\end{array}$ & \\
\hline \multicolumn{5}{|l|}{ Has a partner } \\
\hline Yes & $\begin{array}{l}8.51 \pm \\
2.82\end{array}$ & $Z=-1.982^{*}$ & $\begin{array}{l}9.74 \pm \\
2.60\end{array}$ & $\begin{array}{l}Z= \\
-4.383^{\star \star}\end{array}$ \\
\hline No & $\begin{array}{l}7.86 \pm \\
2.80\end{array}$ & & $\begin{array}{l}8.39 \pm \\
2.88\end{array}$ & \\
\hline \multicolumn{5}{|c|}{ Pornography use during adolescence } \\
\hline Yes & $\begin{array}{l}8.14 \pm \\
2.82\end{array}$ & $Z=-1.054$ & $\begin{array}{l}8.98 \pm \\
2.95\end{array}$ & $Z=-1.238$ \\
\hline
\end{tabular}




\begin{tabular}{|c|c|c|c|c|}
\hline VARIABLE & NURSING & CONTRAST & MEDICINE & CONTRAST \\
\hline No & $\begin{array}{l}8.44 \pm \\
2.86\end{array}$ & & $\begin{array}{l}9.31 \pm \\
2.65\end{array}$ & \\
\hline \multicolumn{5}{|c|}{$\begin{array}{l}\text { Self-perception of their knowledge about sexuality and contraceptive } \\
\text { methods }\end{array}$} \\
\hline Good & $\begin{array}{l}8.43 \pm \\
2.85\end{array}$ & \multirow[t]{3}{*}{$\chi^{2}=2.148$} & $\begin{array}{l}9.38 \pm \\
2.82\end{array}$ & \multirow[t]{3}{*}{$\chi^{2}=1.421$} \\
\hline Regular & $\begin{array}{l}8.41 \pm \\
2.86\end{array}$ & & $\begin{array}{l}9.17 \pm \\
2.70\end{array}$ & \\
\hline Bad & $\begin{array}{l}7.90 \pm \\
2.75\end{array}$ & & $\begin{array}{l}8.83 \pm \\
2.82\end{array}$ & \\
\hline \multicolumn{5}{|l|}{ Had penetrative sex } \\
\hline Yes & $\begin{array}{l}8.48 \pm \\
2.82\end{array}$ & \multirow[t]{2}{*}{$\begin{array}{l}Z= \\
-2.685^{\star \star}\end{array}$} & $\begin{array}{l}9.83 \pm \\
2.68\end{array}$ & \multirow[t]{2}{*}{$\begin{array}{l}Z= \\
-7.648^{\star \star}\end{array}$} \\
\hline No & $\begin{array}{l}7.44 \pm \\
2.72\end{array}$ & & $\begin{array}{l}7.25 \pm \\
2.21\end{array}$ & \\
\hline Age at first intercourse & & $\begin{array}{l}R h o= \\
-0.073\end{array}$ & & $\begin{array}{l}R h o= \\
-0.030\end{array}$ \\
\hline \multicolumn{5}{|c|}{ Use of any contraceptive method during first intercourse } \\
\hline Yes & $\begin{array}{l}8.41 \pm \\
2.79\end{array}$ & \multirow[t]{2}{*}{$Z=-1.305$} & $\begin{array}{l}9.84 \pm \\
2.73\end{array}$ & \multirow[t]{2}{*}{$Z=-0.145$} \\
\hline No & $\begin{array}{l}9.08 \pm \\
3.01\end{array}$ & & $\begin{array}{l}9.71 \pm \\
2.34\end{array}$ & \\
\hline \multicolumn{5}{|c|}{ Contraceptive method used during first intercourse } \\
\hline Male condom & $\begin{array}{l}8.35 \pm \\
2.78\end{array}$ & \multirow[t]{3}{*}{$\chi^{2}=4.089$} & $\begin{array}{l}9.77 \pm \\
2.78\end{array}$ & \multirow[t]{3}{*}{$\chi^{2}=2.348$} \\
\hline Hormonal contraceptive methods & $11 \pm 2.55$ & & $\begin{array}{l}10.57 \pm \\
2.19\end{array}$ & \\
\hline Withdrawal method & $7.5 \pm 0.71$ & & $8 \pm 0$ & \\
\hline \multicolumn{5}{|c|}{ Use of any contraceptive method during most recent intercourse } \\
\hline Yes & $\begin{array}{l}8.52 \pm \\
2.84\end{array}$ & \multirow[t]{2}{*}{$Z=-0.467$} & $\begin{array}{l}9.89 \pm \\
2.60\end{array}$ & \multirow[t]{2}{*}{$Z=-0.652$} \\
\hline No & $\begin{array}{l}8.26 \pm \\
2.69\end{array}$ & & $\begin{array}{l}9.41 \pm \\
3.22\end{array}$ & \\
\hline \multicolumn{5}{|c|}{ Contraceptive method used during the most recent intercourse } \\
\hline Male condom & $\begin{array}{l}8.03 \pm \\
2.93\end{array}$ & \multirow[t]{3}{*}{$\begin{array}{l}\chi^{2}= \\
15.402 \star \star\end{array}$} & $\begin{array}{l}9.54 \pm \\
2.63\end{array}$ & \multirow[t]{3}{*}{$\chi^{2}=6.685^{\star}$} \\
\hline Hormonal contraceptive methods & $\begin{array}{l}9.66 \pm \\
2.30\end{array}$ & & $\begin{array}{l}10.55 \pm \\
2.45\end{array}$ & \\
\hline Withdrawal method & $\begin{array}{l}7.33 \pm \\
3.22\end{array}$ & & $\begin{array}{l}9.67 \pm \\
2.08\end{array}$ & \\
\hline \multicolumn{5}{|l|}{ Knowledge about FPCs } \\
\hline Yes & $\begin{array}{l}8.95 \pm \\
2.78\end{array}$ & \multirow[t]{2}{*}{$\begin{array}{l}Z= \\
-2.710 * \star\end{array}$} & $\begin{array}{l}10.40 \pm \\
2.69\end{array}$ & \multirow[t]{2}{*}{$\begin{array}{l}Z= \\
-6.304^{\star *}\end{array}$} \\
\hline No & $\begin{array}{l}7.98 \pm \\
2.79\end{array}$ & & $\begin{array}{l}8.46 \pm \\
2.63\end{array}$ & \\
\hline
\end{tabular}


Eight variables were introduced into the model for the Medical degree. The model consisted of 4 predictors, with a high correlation among them and the knowledge scale score (0.574), and has an explanatory power of $31.8 \%$ of the variance. The ANOVA for the multiple regression model showed a statistically significant relationship $F=27.318 ; p<0.001$. The collinearity of the model by the model conditioning index obtained a value of 17.034 , considered moderate collinearity. The Durbin Watson statistic obtained a value of 2.113 , so the residuals were considered independent.

For the Nursing degree, 8 variables were also introduced into the model, but the age variable was excluded because of collinearity problems with the rest of the variables. The values of the model were calculated with the remaining 7 variables, obtaining a final model composed of 5 predictor variables. The variables of the final model presented a moderate correlation value (0.497), with an explanatory capacity of $22.7 \%$. The ANOVA for the multiple regression model also showed a statistically significant relationship $F=9.115 ; p<0.001$. Collinearity was also moderate (16.056), and the Durbin Watson statistic was 1.763; therefore, the residuals were considered independent. Table 3 shows the values of the predictor variables for both models.

Table 3

Model values for the scale of knowledge about sexuality and contraceptive in nursing and medicine degree students.

\begin{tabular}{|llll|}
\hline Medical degree & & & \\
\hline Variable & Beta & $p$ & Correlation coefficient \\
\hline Academic year & 0.460 & $<0.001$ & 0.486 \\
\hline Gender & 0.195 & 0.001 & 0.229 \\
\hline Knowledge about FPCs & 0.165 & 0.004 & 0.193 \\
\hline Contraceptive method used during the most recent intercourse & 0.114 & 0.040 & 0.137 \\
\hline Nursing degree & & & \\
\hline Variable & Beta & $p$ & Correlation coefficient \\
\hline Received training during the university degree & 0.504 & $<0.001$ & 0.395 \\
\hline Academic year & -0.385 & $<0.001$ & -0.131 \\
\hline Contraceptive method used during the most recent intercourse & 0.205 & 0.001 & 0.227 \\
\hline Knowledge about FPCs & 0.145 & 0.024 & 0.160 \\
\hline Sex & 0.131 & 0.036 & 0.149 \\
\hline Abbreviation: FPC, Family planning center & & & \\
\hline
\end{tabular}

\section{Discussion}

The education of healthcare students on sexuality and contraception is a key element in ensuring that they are reliable sources of health information in the future. The level of knowledge of all participants in our study was good after they had received specialized training as part of their university degree. Our result contrasts with previous research on the level of knowledge of university healthcare students [16,18], where a low level of knowledge was found. These differences may be because the study by Htay et al. [16] evaluated students during their last year of medical school. However, our data reveal that there is a slight decrease in the years following sexuality training due to a loss of knowledge over time, although this was only evident in the Nursing degree students. Therefore, the effect of the participant's age and the time at which sexuality training on the subject took place should be considered.

The variability in the level of knowledge between the two degrees may be related to the teaching methodologies used. An educational intervention carried out at the University of Jaén, where students of the Nursing degree were trained using a peer education methodology, which incorporated a clinical simulation activity using role play for different clinical scenarios, found a statistically significant improvement in the level of knowledge following the educational intervention, and an improvement in attitudes toward using contraception, with more positive attitudes among participants who had used a contraceptive method in their last sexual 
intercourse [19]. This experience highlights the need to modify the teaching methodologies used for sexuality education from a topdown methodology, where a trained teacher delivers content to a passive audience, to a participatory methodology that engages participants in an active role. Incorporating a more active and dynamic education on sexuality and contraception for young people can help break down or remove the barrier of addressing a taboo subject by encouraging open conversation about an individual's concerns.

Health professionals may present some barriers to training on this topic, as Blakey and Aveyard [20] found in their systematic review, where they show that professionals lack models or training structures on how sexuality should be addressed to train young people. Another barrier they identified was that health professionals perceived their knowledge of sexuality and contraception to be low, which is in line with our research [20]. Only one-third of our sample perceived their level of knowledge as good, which is not consistent with the level of knowledge presented in the numerical rating. This may indicate a low self-perception of knowledge level and highlights a need to develop activities to build up not only conceptual attitudes but also communicative attitudes that allow them to approach the subject with greater confidence.

The level of knowledge was significantly higher in female participants in both groups, similar to previous research, where women showed better results in questions not related to knowledge of the male condom [21,22]. In the present study, the primary educational gaps in both groups were found in items related to the use of hormonal contraceptive methods, which may explain this difference. Another possible explanation may be due to the differential impact that an unwanted pregnancy may have during the formative stage, which may mean that women are more likely to have a greater predisposition to acquire the knowledge to prevent this [23].

An aspect shown in previous research that we have also found in our study is the importance of FPCs in addressing the issue of sexuality and contraceptive education. This result highlights the importance of obtaining information from quality sources such as health professionals in these centers [14,24]. Related to this difference in the level of knowledge, we highlight the finding that those who used some type of hormonal contraceptive method during the most recent intercourse obtained higher scores on the scale. This may be explained by a difference in knowledge according to sex, where women, being the ones who are going to use this contraceptive method, have received more in-depth education regarding this method $[21,22,25,26]$. Alternatively, due to these contraceptive methods requiring a medical prescription, women have obtained information through a health professional, while young people who used the male condom, which is over-the-counter, did not need to talk to a health professional to obtain it [27].

To achieve a risk-free experience of sexuality and an increase in the rate of contraceptive use, we need to look at it from a gender perspective and gain a deeper understanding of the perceptions that may lead to non-use of contraception. Our research asked about the main reasons for not using any contraceptive method in previous sexual relations. We found aspects related to the use of the male condom and the sexual practice itself-"they take away pleasure"-and related to the unpredictability of sexual relations and the associated adrenergic discharge-"sexual relations were improvised"-; results, similar to previous research, where only the reasons for not using the male condom were addressed [28]. This result highlights the importance of promoting contraceptive options other than the male condom through future training strategies.

From our research findings on the primary sources of information used by young people, we found an increasing demand for digital media. In fact, the internet was the main source of information, a finding consistent with previous research [12,13], which leads us to highlight the importance of creating a mobile application where quality content can be accessed. This content should include information about the main face-to-face resources to access qualified health professionals based on their access preferences, and in this way, improve the access of this population group to the relevant quality education [29].

Among the possible limitations of our study, we highlight that as a voluntary survey, the motivation of participants to participate may affect the results. The level of knowledge measured may be affected by this motivation, and the selected population segment may cause an overestimation or underestimation of the value analyzed. On the other hand, being a taboo subject, participants may not fully disclose their reality about previous sexual relations, which may cause the rate of contraceptive use in previous sexual relations reported by participants to be overestimated. As a strength of our study, we highlight that it is a novel study describing the main gaps in knowledge found in young nursing and medical students, which could serve as a basis for developing new training strategies to improve the education of future health professionals.

\section{Conclusion}


The general level of knowledge of the healthcare degree students was high and sufficient to be able to respond as future health professionals to the demands placed on them, both at a personal and professional level. The main training gap we found in both groups was for hormonal contraceptive methods. This aspect should be emphasized in future training programs, without ignoring the gender gap found in the level of knowledge. Further research is needed on behavioral patterns among both sexes that may affect the level of knowledge and use of different contraceptive options in future sexual relations.

\section{List Of Abbreviations}

SD: Standard Deviation.

FPCs: Family Planning Centers.

ANOVA: Analysis of Variance.

\section{Declarations}

\section{Ethical approval and consent to participate.}

All methods were carried out in accordance with relevant guidelines and Regulations. This study was approved by the Institutional Review Board of the University of Jaén (ABR.17/9) and the Research Ethics Committee of the "Hospital Clínico San Carlos" (20/815-E). An information sheet was given to the participants. If happy to participate, students completed and signed an informed consent form prior to undertaking the session. Students were not obliged to participate and were reassured that this would not affect their progress and success in their course of study. Confidentiality of personal data was guaranteed.

\section{Consent for publication.}

Participants were informed and agreed to have their data published in a scientific article.

\section{Availability of data and materials}

All data generated or analysed during this study are included in this published article [Supplementary file 1].

\section{Competing Interests}

The authors declare that they have no competing interest.

\section{Funding}

None to declare.

Authors Contributions.

JPSP, CAN and SSM designed the study. Data was collected by JPSP, AM, FM, CAG, LOD and SSM. Data analysis were done by SSM and CAN. The main manuscript text was written by JPSP, CAG, LOD, MZCC, IMLM, CAN and SSM. All authors reviewed the manuscript. The author(s) read and approved the final manuscript.

\section{Acknowledgement.}

We would like to thank all the students of the Nursing and Medical degree who participated voluntarily in this research.

\section{References}

1. World Health Organization. Reproductive Health Strategy. World Health Organization. Geneva, Switzerland; 2018

2. Toro J. El adolescente en su mundo: Riesgos, problemas y trastornos. Pirámide. Madrid; 2010.

3. Asut O, Ozenli O, Gur G, Deliceo E, Cagin B, Korun O, et al. The knowledge and perceptions of the first year medical students of an International University on family planning and emergency contraception in Nicosia (TRNC). BMC Womens Health. 2018;18: 149. 
4. Kumi-Kyereme A. Sexual and reproductive health services utilization amongst in-school young people with disabilities in Ghana. Afr J Disabil. 2021;10: 671

5. Coronado PJ, Delgado-Miguel C, Rey-Cañas A, Herráiz MA. Sexual and reproductive health in Spanish University Students. A comparison between medical and law students. BMJ Sex Reprod Health. 2017; 11:97-101.

6. Lete I, Hassan F, Chatzitheofilou I, Wood E, Mendivil J, Lambrelli D, et al. Direct costs of unintended pregnancy in Spain. Eur J Contracept Reprod Health Care. 2015;20(4):308-18.

7. Polanco MDG. Las conductas sexuales de riesgo de los adolescentes españoles. RqR Enferm Comunitaria. 2014;2(2):38-61.

8. World Health Organization. Sexually Transmitted Infections among adolescents. World Health Organization; 2005. Available at: https://apps.who.int/iris/bitstream/handle/10665/43221/9241562889.pdf;jsessionid=F8B73C559EBC94667E24A52ADFF7E3F5? sequence=1

9. Ministerio de Sanidad, Consumo y bienestar social. Vigilancia Epidemiológica de las Infecciones de Transmisión Sexual en España, 2017. Gobierno de España. 2019. Disponible en:

https://www.mscbs.gob.es/ciudadanos/enfLesiones/enfTransmisibles/sida/vigilancia/Vigilancia_ITS_1995_2017_def.pdf

10. Vázquez J, Domech L, Nascimento M, Agulló-Tomás E. Evolución de la salud sexual de la población adolescente española y asturiana. Rev Esp Salud Pública. 2020.

11. González M, Fernández ME, Urturi A, Moreno MF, Molinero L, Hernando C. Hábitos sexuales en los adolescentes de 13 a 18 años. Pediatría Aten Primaria. 2015; 17(67):217-25.

12. Hacker KA, Amare Y, Strunk N, Horst L. Listening to youth: Teen perspectives on pregnancy prevention. J Adolesc Health. 2000; 26: 279-88.

13. Serrano I, Dueñas JL, Bermejo R, Coll C, Doval JL, Lete I, et al. Actividad sexual e información y uso de métodos anticonceptivos en la juventud española: resultados de una encuesta nacional. Progresos de Obstetricia y Ginecología. 2005; 48: $283-8$.

14. Sanz-Martos S, López-Medina IM, Álvarez-García C, Clavijo-Chamorro MZ, Ramos-Morcillo AJ, Rodríguez-López MM, et al. Young Nursing Student's Knowledge and Attitudes about Contraceptive Methods. Int J Environ Res Public Health. 2020; 17.

15. Munakampe MN, Zulu JM, Michelo C. Contraception and abortion knowledge, attitudes and practices among adolescents from low and middle-income countries: a systematic review. BMC Health Serv Res. 2018; 18.

16. Htay MNN, Latt SS, Abas AL, Chuni N, Soe HHK, Moe S. Medical students' knowledge and perception toward family planning services: A preliminary intervention study. J Educ Health Promot. 2018; 7:137.

17. Sanz-Martos S, López-Medina IM, Álvarez-García C, Álvarez-Nieto C. Sexuality and contraceptive knowledge in university students: instrument development and psychometric analysis using item response theory. Reprod Health. 2019; 16: 127.

18. McKelvey RS, Webb JA, Baldassar LV, Robinson SM, Riley G. Sex Knowledge and Sexual Attitudes Among Medical and Nursing Students. Aust N Z J Psychiatry. 1999;33(2):260-6.

19. Sanz-Martos S, López-Medina IM, Álvarez-García C, Álvarez-Nieto C. Educational program on sexuality and contraceptive methods in nursing degree students. Nurse Educ Today. 2021; 107.

20. Blakey EP, Aveyard H. Student nurses' competence in sexual health care: A literature review. J Clin Nurs. 2017; 16: 3906-16.

21. Darteh EK, Doku D. Knowledge and usage of emergency contraceptives among university students in Ghana. J Community Health. 2016; 41: 15-21.

22. Muanda FM, Gahungu NP, Wood F, Bertrand JT. Attitudes toward sexual and reproductive health among adolescents and young people in urban and rural DR Congo. Reprod Health. 2018; 15: 74.

23. Munive MV, Cárdenas AR, Castro AR. Conocimientos, actitudes y prácticas en salud sexual entre estudiantes de los primeros semestres de enfermería. Revista de la Facultad de Ciencias de la Salud. 2010;7(2):211-8.

24. White AL, Mann ES, Larkan F. Contraceptive knowledge, attitudes, and use among adolescent mothers in the Cook Islands. Sex Reprod Health. 2018; 16: 92-7.

25. Sohbet R, Geçici F. Examining the Level of Knowledge on Sexuality and Reproductive Health of Students of Gaziantep University. Sex Disabil. 2013; 32: 75-84.

26. Kgosiemang B, Blitz J. Emergency contraceptive knowledge, attitudes and practices among female students at the University of Botswana: A descriptive survey. Afr J Prim Health Care Fam Med. 2018; 10(1): 1674. 
27. Prats E, Fernández VJ. Dispensación de anticonceptivos orales según el consenso de atención farmacéutica. Offarm. 2004;23(11):76-85.

28. Provenzano S, Santangelo OE, Terranova A, D`anna G, Grigis D, Firenze A. Investigate the sexual habits of young people: A crosssectional study among nursing students of the university of Palermo. Acta biomed. 2020; 13(91): 50-7.

29. Brayboy LM, Sepolen A, Mezoian T, Schultz L, Landgren-Mills BS, Spencer N, et al. Girl talk: A smartphone application to teach sexual health education to adolescent girls. J Pediatr Adolesc Gynecol. 2017; 30: 23-8

\section{Supplementary Files}

This is a list of supplementary files associated with this preprint. Click to download.

- Suplementaryfile1.xls 